\title{
Evaluation of Phytochemical, Anti-nutritional and Antioxidant Potentials of Flower and Seed Methanol Extracts of Senna alata L. Grown in Nigeria
}

\author{
Abubakar Isah", Mann Abdullahi, Mathew John Tsado \\ Department of Chemistry, Federal University of Technology, Minna, Niger State, Nigeria
}

Email address:

abubakis@mtnnigeria.net (A. Isah)

To cite this article:

Abubakar Isah, Mann Abdullahi, Mathew John Tsado. Evaluation of Phytochemical, Anti-nutritional and Antioxidant Potentials of Flower and Seed Methanol Extracts of Senna alata L. Grown in Nigeria. American Journal of Applied Chemistry. Vol. 3, No. 3, 2015, pp. 93-100. doi: 10.11648/j.ajac.20150303.12

\begin{abstract}
Senna alata L., commonly known as Candlestick senna or Wild senna belongs to the family Caesalpiniaceae is widely distributed in Northern Nigeria. It has been used frequently in herbal medicine to treat different kinds of pathogenic conditions, particularly as laxative or purgative and in the treatment of skin infections as such as ring worm, impetigo, syphilis, sores, psoriasis, herpes, scabies, rashes, and itching. The rate at which this plant parts (flowers and seeds) have been frequently used in Nupe ethnomedicine led to the increase interest to determine the phytochemical, anti-nutritive and antioxidant activities of the flower and seed of Senna alata L. grown in Bida Niger State, Nigeria using standard analytical methods. Phytochemical screening of the flower and seed of the plant revealed the presence of flavonoids, phenols, saponins, tannins, alkaloid and anthraquinone, steroid and cardiac glycosides, were slightly present, while resins was absent. The metabolites present were quantitatively determined with alkaloid contents of $10.23 \pm 0.35$ and $8.41 \pm 0.76$ saponins $25.72 \pm 0.83$ and $28.84 \pm 0.44$, flavonoids $28.52 \pm 0.47$ and $32.25 \pm 0.52$, tannins $32.98 \pm 0.74$ and $39.99 \pm 0.37$, phenols $4.24 \pm 0.76$ and $6.31 \pm 0.68 \mathrm{mg} / 100 \mathrm{~g}$ for flower and seed respectively. These results confirm that these metabolites obtained from the two parts of this plant were within the range of toxicity levels according to World Health Organization safe limits. The results of anti-nutritional factors revealed the oxalate contents with $4.24 \pm 0.12$ and $6.31 \pm 0.41$, cyanide content $8.59 \pm 0.71$ and $4.89 \pm 0.69$ and phytate content $17.54 \pm 0.63$ and $13.72 \pm 0.81 \mathrm{mg} / 100 \mathrm{~g}$ for flower and seed respectively. The values of anti-nutritional factors obtained from this work show that they may not pose any effects based on their toxicity levels and as recommended by World Health Organization. The major components of the chemical compounds deduced from GC/MS for the two parts of this plant investigated revealed the presence of $\beta$-d-mannofuranoside (24.23\%), n-hexadecanoic acid (19.20\%), oleic acid (28.27\%), nonadecanoic acid (5.36\%), 3, 11-tetradecadien-1-ol (3.79\%) and octadecanal (17.22\%), oleic acid (50.21\%), octadecanoic acid (7.14), n-hexadecanoic acid (34.16\%), pentanoic acid (3.39\%) and 2-ethyl-1-decanol (2.21\%). Some of these phytoconstituents like n-hexadecanoic and oleic are responsible for the said pharmacological activities. Thus, properly domesticated and utilization of this plant will serve as source of bioactive agents for pharmaceutical industries.
\end{abstract}

Keywords: Antioxidant, Phytochemical, Anti-nutritional, Flower, Seeds, Senna alata

\section{Introduction}

Plants have displayed great versatility in synthesizing complex secondary metabolites which have no obvious growth metabolic functions. Some of these metabolites are responsible for the characteristic odours, pungencies and colours of plants while others give a particular role in plant that such as its culinary, medicinal or poisonous virtues [1]. There has been reports by different researchers that any plant that have activities against any clinical pathogens contain an active principles such as alkaloids, saponins and flavonoids which may completely replace the plant extract [2]. These phytochemicals found in plants that are used in the treatment of disease contain bioactive compounds that responsible for the biological activity. Therefore, plants are natural sources of bioactive compounds to treat life threatening diseases. Presently, about $25 \%$ of drugs contain at least one plantderived ingredient [3]. In the last century, roughly 121 pharmaceutical products were formulated based on the traditional knowledge obtained from various natural sources 
[4]. Plants help in health benefits above basic nutritional needs as usually believed by many people all over the World [5]. Natural phytochemicals derived from medicinal plants have gained a lot of recognition in the treatment and management of various diseases in the past two decades [6]. Natural products have the potential to provide medicine with a source of novel structures that are unobtainable from sources such as combinatorial synthesis [7]. The interest in natural product for treatments of diseases has attracted most pharmaceutical companies interested in commercializing phytomedicine [8].

Antioxidants protect other molecules from oxidation when they are exposed to free radicals and reactive oxygen species (ROS) which have been implicated in the protection of diseases and in food deterioration and spoilage [9]. The use of free radical scavenging assays in assessing the cell membrane integrity/cell membrane stabilising capacities of plant constituents has given explanations as to the possible ways by which phytomedicines could help to reduce diseases caused by infections, inflammation and oxygen radicals generation affecting the cell membrane [10]. Interest has increased considerably in finding naturally occurring antioxidants from plants because of their potential in health promotion and disease prevention, and their high safety and consumer acceptability [11]. The ingestion of fresh fruit, vegetables and tea rich in natural antioxidants has been associated with prevention of cancer and cardiovascular diseases [12].

For several centuries, the knowledge of medicinal plants and screening techniques has always guided the search for new drugs or phytomedicine [13]. Spectroscopic technique like GC-MS is the excellent diagnostic tool to qualitatively and quantitatively determine the bioactive components alkaloids, glycosides, flavonoids, phenol, tannins and terpenoids and amino acids that are present in plant extracts [13]. The models of free radical scavenging commonly employed for evaluating antioxidant activities is based on their abilities to donate hydrogen ion [14]. The methanolic solution gives a purple colouration which when reduced by an antioxidant molecule gives rise to a yellow solution. On comparison with ascorbic acid, a standard antioxidant drug with the antioxidant activities of the extracts. It is therefore desirable to identify several constituents present in the methanol extracts of the Senna alata flower and seed. Most of the compounds possess medicinal properties whereas certain components reported in this work have not been reported in literature before. Best of our knowledge and literature survey there is no report of GCMS analysis to identify the chemical compounds from the methanol extract of the Senna alata flower and seed.

\section{Materials and Methods}

\subsection{Collection, Identification and Preparation of Plant Material}

Leafy plant of $S$. alata was obtained from Edokota forest along Bida-Zungeru road, Bida, Niger State, Nigeria. The identity was confirmed by plant taxonomist from the National Institute Pharmaceutical Research Development, Idu-Abuja where a voucher specimen was deposited with Herbarium No.1369. The samples (flower and seed) collected from the experimental sites were washed with distilled water to remove the impurities and dried at room temperature. These were then ground into uniform powder manually. It was then sieved, weighed, bottled, labelled and used for laboratory analysis.

\subsection{Extraction of the Plant Extracts}

Powdered flower and seed of $S$. alata were extracted with $70 \%$ aqueous methanol at room temperature. The extract solution of each sample was filtered, and the solvent was evaporated under reduced pressure at $35^{\circ} \mathrm{C}$.

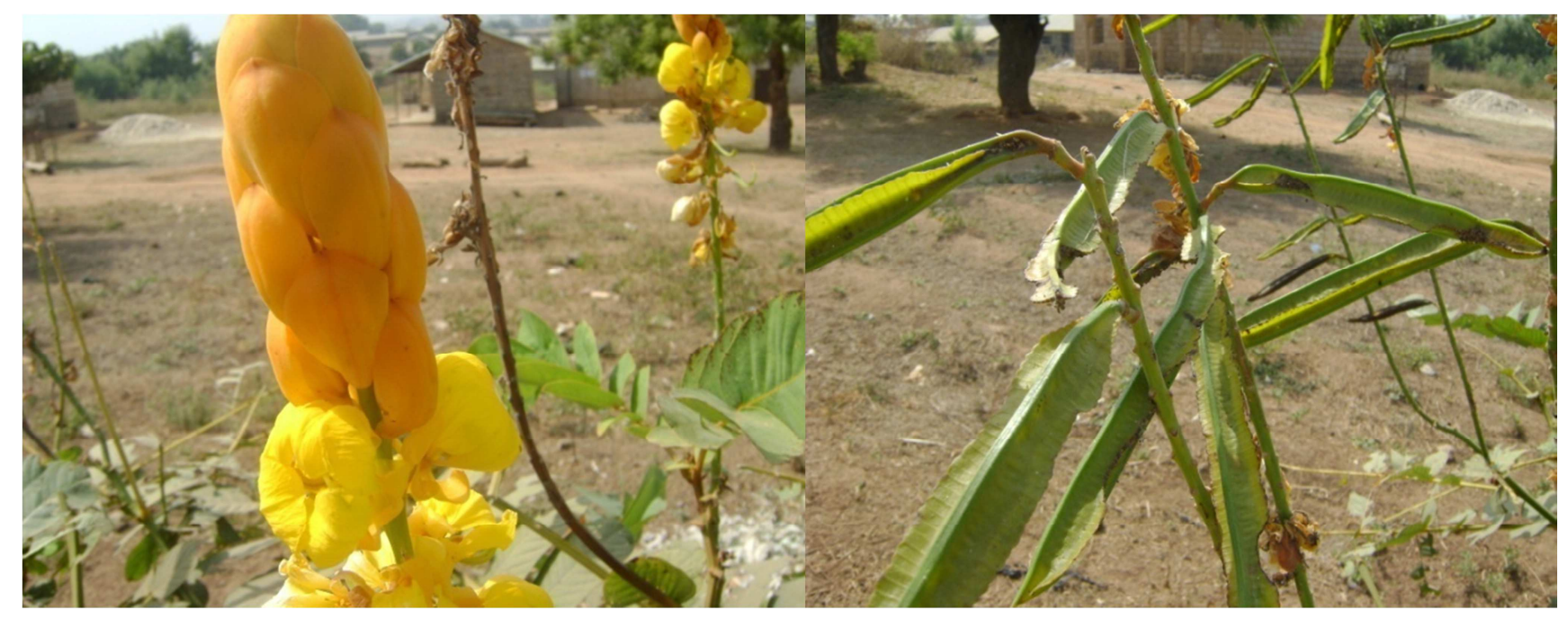

Figure 1. Aerial parts depicting flowers and fruits of Senna alata (A. Mann).

\subsection{Qualitative Phytochemical Screening of the Samples}

Phytochemical screening procedures carried out were adopted from Mann [15], where tannins, saponins, steroids, alkaloids, cardiac glycoside, terpenoids and flavonoids were determined. 


\subsection{Quantitative Phytochemical Analysis of the Samples}

Standard analytical methods were used for the quantitative phytochemical analysis of these samples [16]. Tannins and saponins were determined using standard method of Onwuka [17], while flavonoids and alkaloids were determined using standard method as described by Harborne, [18]. and the total phenolic content was estimated using the modified FolinCiocalteu photometric method by Schuler, [19].

\subsection{Anti-nutritional Properties of the Samples}

Oxalate and cyanide contents were determined using the method of Day and Underwood, [20]. Phytate content was determined by the method described by Wheeler and Ferrel [21].

\subsection{Antioxidants Activities of the Samples}

The ferric reducing antioxidant power (FRAP) assay was done according to Benzie and Strain, [22] with some modifications while total phenolics of various fractions of plant were determined by reported method of Valentao et al. [23].

\subsection{GC/MS Analysis of the Samples}

GC-MS analysis was carried out on a Shimadzu (Kyoto, Japan) GC-MS model QP 2010 at National Research Institute for Chemical Technology, Zaria, according to the EN 14103 standard method [24] [25]. The GC column oven temperature $\left(70^{\circ} \mathrm{C}\right)$, injecting temperature $\left(250^{\circ} \mathrm{C}\right)$, flow control mode (linear velocity), total flow $(40.8 \mathrm{ml} / \mathrm{min})$ column flow $(1.80$ $\mathrm{ml} / \mathrm{min})$, pressure $(116.9 \mathrm{kpa})$, linear velocity $(49.2 \mathrm{~cm} / \mathrm{sec})$ and purge flow $(3.0 \mathrm{ml} / \mathrm{min})$ were employed for this analysis.
A sample volume of $8.0 \mu \mathrm{L}$ was injected using split mode (split ratio of 20.0). The peak area, that is, the \% amount of every component was calculated by comparing its average peak area to the total areas. Software was used to handle mass spectra and chromatogram.

\subsection{Identification of Components from the Samples}

Interpretation of mass spectrum GC-MS was conducted by comparing the database peaks of National Institute Standard and technology (NIST) library with those reported in literature, the mass spectra of the peaks with literature data [26]. The spectrum of the unknown component was compared with the spectrum of the known components stored in the NIST library. Component relative percentages were calculated based on GC peak areas without using correction factors. The Name, Molecular weight and structure of the components of the test materials were ascertained.

\subsection{Statistical Analysis}

All the experiments were conducted in triplicate unless stated otherwise and statistical analysis of the data was performed by analysis of variance (ANOVA), using SPSS 11.0 for Windows software. A probability value of difference $\mathrm{p} \leq$ 0.05 was considered to denote a statistically significance. All data were expressed as mean values \pm standard deviation (SD).

\section{Results and Discussion}

\subsection{Plant Extract Yields}

The yellowish and light yellow masses were obtained with $4.50 \%$ and $1.50 \%$ yield for flower and seed respectively in this study.

Table 1. Qualitative phytochemical evaluation of methanol extracts of Senna alata flower and seed.

\begin{tabular}{|c|c|c|c|}
\hline Chemical Constituents & Chemical test & Methanol flower extract & Methanol seed extract \\
\hline \multirow[t]{2}{*}{ Alkaloids } & Hager's test & + & + \\
\hline & Wagner's test & + & + \\
\hline Tannins & Tannin test & + & + \\
\hline Anthraquinone & Anthraquinone test & + & + \\
\hline Saponins & Foam's test & + & + \\
\hline \multirow[t]{3}{*}{ Glycosides } & Borntrager's test & + & + \\
\hline & Liebermann Buchard's test & + & + \\
\hline & Legal's test & + & + \\
\hline \multirow[t]{2}{*}{ Triterpenes and Phytosterols } & Salkowski's test & + & + \\
\hline & Lieberman Buchard's test & + & + \\
\hline Phenols & Ferric chloride tests & + & + \\
\hline \multirow[t]{3}{*}{ Flavonoids } & Sodium hydroxide test & + & + \\
\hline & Lead acetate test & + & + \\
\hline & Shinoda test & - & - \\
\hline Resins & Acetone-water test & + & + \\
\hline
\end{tabular}

$+=$ Indicates presence, $-=$ Indicates absence 
Table 2. Quantitative evaluation of Methanol Extracts of Senna alata flower and seed ( $\mathrm{mg} / 100 \mathrm{~g}$ ).

\begin{tabular}{lll}
\hline Chemical Constituents & & Samples \\
\hline & Flower & Seed \\
Alkaloids & $10.23 \pm 0.35$ & $8.41 \pm 0.76$ \\
Saponins & $25.72 \pm 0.83$ & $28.84 \pm 0.44$ \\
Flavonoids & $28.52 \pm 0.47$ & $32.25 \pm 0.52$ \\
Tannins & $32.98 \pm 0.74$ & $39.99 \pm 0.37$ \\
Phenols & $4.24 \pm 0.76$ & $6.31 \pm 0.68$ \\
\hline
\end{tabular}

values are means $\pm \mathrm{SD}$ of three determinations

Different superscripts along the same row are significantly different $(\mathrm{p} \leq 0.05)$

Table 3. Anti-nutrient factors of flower and seed of Senna alata $(\mathrm{mg} / \mathrm{l00g})$.

\begin{tabular}{lll}
\hline Anti-nutrient constituents & & Samples \\
\hline & Flower & Seed \\
Oxalate & $4.24 \pm 0.12$ & $6.31 \pm 0.41$ \\
Cyanide & $8.59 \pm 0.71$ & $4.89 \pm 0.69$ \\
Phytate & $17.54 \pm 0.63$ & $13.72 \pm 0.81$ \\
\hline
\end{tabular}

Values are means $\pm \mathrm{SD}$ of three determinations

Different superscripts along the same row are significantly different $(\mathrm{p} \leq 0.05)$

Table 4. Determination of Antioxidant contents of flower and seed of Senna alata.

\begin{tabular}{lll}
\hline Antioxidant contents & \multicolumn{1}{c}{ Samples } & Seed \\
& & \\
Phenolic properties $(\mathrm{mg} / \mathrm{g})$ & $4.16 \pm 0.21$ & $4.01 \pm 0.11$ \\
Ferric reducing properties $(\mu \mathrm{mol} / \mathrm{mg})$ & $0.33 \pm 0.51$ & $0.40 \pm 0.21$ \\
\hline
\end{tabular}

Values are means $\pm \mathrm{SD}$ of three determinations

Different superscripts along the same row are significantly different $(\mathrm{p} \leq 0.05)$

Table 5. Chemical compounds deduced from GC-MS spectrum of Senna alata flower.

\begin{tabular}{llllll}
\hline Line no & IUPAC Name & Molecular formula & Molar mass & RT & Area \% \\
\hline 1 & B-d-Mannofuranoside & $\mathrm{C}_{7} \mathrm{H}_{14} \mathrm{O}_{6}$ & 194 & 14.554 & 24.23 \\
2 & n-Hexadecanoic acid & $\mathrm{C}_{16} \mathrm{H}_{32} \mathrm{O}_{2}$ & 256 & 16.625 & 19.20 \\
3 & 9-Dodecenoic acid & $\mathrm{C}_{13} \mathrm{H}_{24} \mathrm{O}_{2}$ & 212 & 17.525 & 1.93 \\
4 & Oleic acid & $\mathrm{C}_{18} \mathrm{H}_{34} \mathrm{O}_{2}$ & 282 & 18.217 & 28.27 \\
5 & Nonadecanoic acid & $\mathrm{C}_{19} \mathrm{H}_{38} \mathrm{O}_{4}$ & 298 & 18.467 & 5.36 \\
6 & 3,11 -Tetradecadien-1-ol & $\mathrm{C}_{14} \mathrm{H}_{26} \mathrm{O}$ & 210 & 20.8 & 3.79 \\
7 & Octadecanal & $\mathrm{C}_{18} \mathrm{H}_{36} \mathrm{O}$ & 268 & 23.975 & 17.22 \\
\hline
\end{tabular}

Table 6. Chemical compounds deduced from GC-MS spectrum of Senna alata seed.

\begin{tabular}{llllll}
\hline Line no & IUPAC Name & Molecular formula & Molar mass & RT & Area \% \\
\hline 1 & n-Hexadecanoic acid & $\mathrm{C}_{16} \mathrm{H}_{32} \mathrm{O}_{2}$ & 256 & 16.448 & 34.16 \\
2 & 15-Tetracosenoic acid & $\mathrm{C}_{25} \mathrm{H}_{48} \mathrm{O}_{2}$ & 380 & 17.401 & 1.79 \\
3 & Oleic acid & $\mathrm{C}_{18} \mathrm{H}_{34} \mathrm{O}_{2}$ & 282 & 18.122 & 50.21 \\
4 & Octadecanoic acid & $\mathrm{C}_{18} \mathrm{H}_{36} \mathrm{O}_{2}$ & 284 & 18.262 & 7.14 \\
5 & 2-Methyl-1-octanol & $\mathrm{C}_{9} \mathrm{H}_{20} \mathrm{O}$ & 144 & 19.208 & 1.1 \\
6 & Pentanoic acid & $\mathrm{C}_{16} \mathrm{H}_{30} \mathrm{O}_{2}$ & 254 & 20.697 & 3.39 \\
7 & 2-Ethyl-1-decanol & $\mathrm{C}_{12} \mathrm{H}_{26} \mathrm{O}$ & 186 & 20.867 & 2.21 \\
\hline
\end{tabular}

\subsection{Discussion of Results}

The results of qualitative analysis of the crude methanolic extract of these parts of $S$. alata shown in Table 1 revealed the presence of tannins, flavonoids, terpenoids, saponins, alkaloids, glycosides and anthraquinone. This analysis determines the biologically active compounds that contribute to the flavour, colour and other characteristics of flowers and seeds which are the basis of therapeutic potentials of medicinal plants. The present results were supported by the earlier reports for some Senna species [27]. The presence of tannins as reported in this work may cause lowering of available protein by antagonistic competition and can therefore elicit protein deficiency syndrome "Kwashiokor" [28]. Saponins may be responsible for its anti-yeast, antifungal, antidote, antimicrobial and anti-inflammatory activities. It is also believed that the role of saponins is to protect plant against attack by potential pathogens [29]. Flavonoids which are also known as vitamin $p$ or plan modifier, elicit a wide range of therapeutic activities as antihypertensive, antirheumatism as well as antimicrobial as identified with flavonoids [30]. Essiett et al. [31] reported that many plants containing flavonoids have diuretic and the antioxidant properties. The flower and seed of this plant can 
equally be used according; glycosides were detected in the extracts and this compound has been useful in the treatment of asthma [32]. Steroids also showed a positive results in some parts of this plant which are of importance and interest in pharmacy due to their relationship with such compounds as sex hormones [33] and promote immune function in the skin and also reduce inflammation [34]. Glycosides showed positive results in the seed and flower of $S$. alata. The glycoside has been used for over two centuries as stimulant in cases of cardiac failure and diseases [35]. This perharps justifies the already locally established function of the plant in the treatment and management of hypertension [36]. Alkaloids have been found to have microbiocidal effect and the major antidiarrheal effect is probably due to their effects on small intestine and antihypertensive antifungal, antiinflammatory, anti fibrogenic effect [37]. However, the result of this work is similar to the findings of McDevitt et al. [38] who reported the presence of alkaloid in Cnidoscolus aconitifolius. Some alkaloids are useful against HIV infection as well as intestinal infection associated with AIDS [39]. The presence of alkaloids in the parts of this medicinal plant makes them recommendable for patient as alkaloids possess a significant pharmacological property. The results of quantitative analysis of the two parts of $S$. alata as presented in Table 2 showed saponins contents which were $28.84 \pm 0.47$ and $25.72 \pm 0.83 \mathrm{mg} / 100 \mathrm{~g}$ for seed and flower respectively. It was observed that saponin concentrations were high in seed while flower had the low content. These results were high compared to $12.1 \mathrm{mg} / 100 \mathrm{~g}$ of $M$. utilis reported by Siddhuraju and Becker, [40]. Saponins are naturally occurring surface - active glycosides. They are mainly produced by plants, but also by lower marine animals and some bacteria [41]. The result of quantitative analysis of alkaloid content obtained from these samples was $8.41 \pm 0.76$ and $10.23 \pm 0.35 \mathrm{mg} / 100 \mathrm{~g}$ for seed and flower respectively. The alkaloid contents were higher in flower than those of seed. This is similar to the values reported for $S$. alata flower $(8.50 \pm 0.01 \mathrm{mg} / 100 \mathrm{~g})$ by Abdulwaliyu et al. [42]. Alkaloids are more or less toxic substances which act primarily on the central nervous system [43]. The tannin contents analyzed in this work were $32.98 \pm 0.0 .74$ and $39.99 \pm 0.37 \mathrm{mg} / 100 \mathrm{~g}$. The concentration was high with $S$. alata seed while flower had the least. The contents of tannin obtained in these work were similar to $46.08 \mathrm{mg} / 100 \mathrm{~g}$ of $M$. utilis reported by Siddhuraju and Becker [40]. The value of flavonoid analyzed from all the samples were $28.52 \pm 0.47$ and $32.25 \pm 0.52 \mathrm{mg} / 100 \mathrm{~g}$ for flower and seed respectively. The flavonoids contents were high with $S$. alata seed while flower had the least. The phenol contents analyzed from this work were $4.24 \pm 0.76$ and $6.31 \pm 0.68 \mathrm{mg} / 100 \mathrm{~g}$ for flower and seed respectively. The concentration of the seed was found to be high, while flower had the least value. These values were high compared to $2.00 \pm 0.21 \mathrm{mg} / 100 \mathrm{~g}$ for $S$. alata leaf reported by Abdulwaliyu et al. [42].

Anti-nutritional factors affect the availability of nutrients required by the body and interfere with metabolic process so that growth and development of the body is negatively influence [44]. The results of anti-nutritional factors obtained for this work were presented in Table 3 . The phytate content in the samples analyzed were $13.81 \pm 0.31$ and $17.54 \pm 0.63$ $\mathrm{mg} / 100 \mathrm{~g}$ for seed and flower respectively. The content of phytates was high with Senna alata flower while seed had the least. Phytate help in adequate iron bioavailability. Mitchikpe et al. [45] reported that for the absorption of iron phytate/Fe should be less than 0.4 . The result obtained in this study was high when compared to the $3.55 \mathrm{mg} / 100 \mathrm{~g}$ of $S$. alata leaf reported by Abdulwaliyu et al. [42]. The contents of oxalates obtained from this work were $4.2 \pm 0.12$ and $6.31 \pm 0.62$ $\mathrm{mg} / 100 \mathrm{~g}$ for flower and seed respectively. The concentrations of oxalate were high with $S$. alata seed while flower had the lowest. Similar values were obtained for the $S$. alata flower $(8.03 \pm 0.06 \mathrm{mg} / 100 \mathrm{~g})$ reported by Abdulwaliyu et al. [42] The presence of oxalate in the food causes irritation in the mouth and interferes with absorption of divalent minerals particularly calcium by forming insoluble salts [46]. The cyanide content in the samples analyzed was $4.89 \pm 0.69$ and $8.59 \pm 0.71 \mathrm{mg} / 100 \mathrm{~g}$ for seed and flower respectively. The contents of cyanide were high with $S$. alata flower while seeds had the lowest. These values are low when compared to the toxic level of $26.05 \pm 0.45 \mathrm{mg} / 100 \mathrm{~g}$, reported for $S$. alata leaf by Abdulwaliyu et al. [42].

The generation of the reactive oxygen species (ROS) beyond what the ability of the body can cope with leads to oxidative stress [47]. Free radical oxidative stress has been implicated in the pathogenesis of a variety of human diseases like: artherosclerosis, diabetes mellitus, hypertension, inflammation, cancer and AIDS [48]. Antioxidant and antimicrobial activities of some African medicinal plants have been reported [49]. Studies have been carried out to evaluate the antioxidant activities of Nigerian medicinal plant extracts [50] [51]. The extracts of various morphological parts possess significant antioxidant activities; Since the antioxidant compounds found in plants have different polarities, different solvents are used to separate antioxidants [52]. Many studies have demonstrated the efficacy of plant derived products as antioxidants against various diseases induced by these free radicals. The flower and seed extracts of $S$. alata showed relatively impressive antioxidant activities and would be good as an antioxidant agent. These results showed that the plant S. alata could be further exploited for chemotherapeutic agents that could be used against pathogenic infections: laxative or purgative and skin infections as such as ring worm, impetigo, syphilis, sores, psoriasis, herpes, scabies, and rashes that common in Nigeria. Alternatively, the extracts and active fractions of these plants may be used directly in ethnomedicine as antimicrobial or antioxidant agents.

Table 4 shows the antioxidant properties obtained from this study using phenolic and ferric reducing properties. The antioxidant values of flower and seed were $4.16 \pm 0.21$ and $4.01 \pm 0.11$ respectively for phenolic properties. Where flower has the highest content of phenolic properties, seed had the lowest value. These values were similar to $3.58 \mathrm{mg} / \mathrm{g}$ reported for S. hirsute by Essiett and Bassey [27]. The ferric 
reducing properties obtained for flower and seed were $0.33 \pm 0.51$ and $0.40 \pm 0.21 \mu \mathrm{mol} / \mathrm{mg}$ respectively. From these results, high ferric reducing properties was recorded for seed $(0.40 \pm 0.21 \mu \mathrm{mol} / \mathrm{mg})$ while flower $(0.33 \pm 0.51 \mu \mathrm{mol} / \mathrm{mg}) \mathrm{had}$ the lowest. These values were higher when compared to $0.17 \pm 0.04 \mu \mathrm{mol} / \mathrm{mg}$ reported for $P$. mirifica by Buran and Supak [53].

Tables 5 and 6 show the phytocomponents identified with GC-MS analysis of the four organs of $S$. alata. It was observed that these organs in this plant contain all important fatty acid needed in the body for proper functioning. The fatty acids recorded in this work are major source of energy. Most diets contain a great deal of fatty acid which was seen in this plant in form of triacylglycerol. Table 5 present the result of $S$. alata flower. The GC-MS spectrum of flower revealed the presence of many major components, namely $\beta$ d-mannofuranoside, Oleic acid, n-hexadecanoic acid, octadecanal and nonadecanoic acid. The percentage concentration for each of the organic acid was also present in the table 5 as 24.23, 28.27, 18.23, 17.22 and $5.36 \%$ respectively. These values observed to be high when compared to $S$. podocarpa used for medicinal purposes in Nigeria reported by Adebayo et al. [54].

Table 6 present the result of GC-MS spectrum $S$. alata seed shows seven (7) compounds, the major components were oleic acid, n-hexadecanoic acid, octadecanoic acid and pentanoic acid with respective percentage concentration for each of the organic compound presented in the table 6 as $50.21,34.16,7.14$ and $3.39 \%$ respectively. The oleic acid content present in the seed is higher than flower which should be more desirable since oleic acid is essential in the human nutrition. Generally in plants, high quantity of unsaturated fatty acids in the oil was advantageous from the nutritional and health aspects. Since consumption of unsaturated fatty acids will not lead to heart related diseases whereas using up of saturated fatty acids rich foods associated with assured cardiovascular disorders such as atherosclerosis, aging and cancer [55]. Therefore, the antioxidant activities may possibly be due to the predominant role played by these compounds in it. The content of $S$. alata seed is observed to be high when compared to $S$. podocarpa used for medicinal purposes in Nigeria as reported by Adebayo et al. [54].

\section{Conclusion}

The present study focused on two parts of $S$. alata obtained from Edokota forest, Bida in Niger State, Nigeria and shows that these parts of the plant can contribute some significant amount for human medical uses. It could be concluded that methanol flower and seed extracts of $S$. alata possesses a number of bioactive compounds, which may be used in the manufacture of phyto-pharmaceutical and therapeutic value. The presence of various bioactive compounds such as alkanes, fatty acids and steroids in these parts of plant can inhibit the growth of micro-organisms justifies the use of this medicinal plant for various ailments by traditional practitioners as antioxidant and antimicrobial properties. However, anti-nutritional factors in the two organs of this plant were low which makes them to be edible. Based on the results obtained in this study, it could be believed that the crude extract of $S$. alata flower and seed powders contain chemical constituents of pharmacological and nutritional significance. So these plant parts are recommended as phytopharmaceutical importance. However, it is recommended that additional work is to be carried out to isolate, characterize and elucidate the individual phytochemical constituents in this medicinal plant responsible for the bio-efficacy and bioactivity required in the discovery of novel herbal drugs.

\section{References}

[1] W. C. Evans and E. Trease, .Pharmacognosy, (15th edition), London W.B. Saunders Company Ltd., 2002, pp. 191-393.

[2] P. J. David,. Centre for Pharmacognosy, The School of Pharmacy, University of London, p 29-39.

[3] D. J. Newman, G. M. Cragg, K. M. Snader, The Influence of Natural Products Upon Drug Discovery. Nat. Prod. Rep., 2000, 17 pp 215-234.

[4] P. Mukeshwar, D. Mousumi, G. Shobit, and K. C. Surender, Phytomedicine: An ancient approach turning into futurepotential source of therapeutics. Journal of Pharmacognosy and Phytotherapy, 2011, 3(1), pp 113-117.

[5] B. O. Oomah, and G. Mazza, Functional foods. In Francis F.J (eds) the Wiley Encyclopedia. 2000.

[6] J. P. Dyana, and G. Kanchana, Preliminary phytochemical screening of Cocos nucifera L. Flowers. International Journal of Current Pharmaceutical Research, 2012, 4, pp 62-63.

[7] G. A. Cordell, Biodiversity and Drug Discovery: A Symbiotic Relationship. Phytochemistry, 2000, 55, pp 463-480.

[8] R. N. Okigbo, and E. C. Mmeka, An appraisal of phytomedicine in Africa. Science Technology Journal, (2006, pp 6.

[9] I. I. Koleva, H. A. G. Niederlander, and T. A. Van Beek, An online HPLC method for detection of radical scavenging compounds in complex mixtures. Analytical Chemistry, 2000, 72, pp 2323-2328.

[10] P. G. Pietta, Flavonoids as antioxidants. J Nat Prod, 2000, 63, pp 1035-42.

[11] S. Gorinstein, K. Yamamoto, E. Katrich, H. Leontowicz, A. Lojek, M. Leontowicz, M. Ciz, I. Goshev, U. Shalev, S. Trakhtenberg, Antioxidative properties of Jaffa sweeties and grapefruit and their influence on lipid metabolism and plasma antioxidative potential in rats. Bioscience Biotechnology Biochemical, 2003, 67, pp 907-910.

[12] J. K. Willcox, S. L. Ash, and G. L. Catignani, Antioxidants and prevention of chronic disease. Critical Revolution Food Science and Nutrition, 2004, 44, pp 275-295. 
[13] M. Elangovan, M. S. Dhanarajan, and I. Elangovan, Determination of Bioactive Compounds from the Petroleum Ether Leaf Extract of Moringa oleifera and Phyllanthus emblica using GC-MS Analysis. World Journal of Pharmaceutical Research, 2015, 4 pp 1284-1298.

[14] S. Kumazawa, M. Taniguchi, Y. Suzuki, M. Shimura, M. Kwon, T. Nakayama, Antioxidant activity of Polyphenols in Carob Pods. .J. Agric. Food Chem. 2002, 50, pp 373-377.

[15] A. Mann, Extraction and Screening Methods for Natural Products Chemistry: Bioassay-Guided Purification of Active Extracts and Structure Elucidation of Phytoconstituents. Research Laboratory Manual for Natural Product Chemistry, Federal University of Technology, Minna, Niger State, Nigeria, 2014, pp1-19.

[16] H. O. Edeoga, D. E. Okwu, and B. O. Mbaebie, Phytochemical constituents of some Nigerian medicinal plants. Afr. J. Biotechnol., 2005, 4 pp 685-688.

[17] G. I. Onwuka, Food Analysis and Instrumentation Theory and Practice.Naphthali print, Nigeria, 2005, pp 63-98.

[18] J. B. Harborne, Biosynthensis and Function ofAntinutritional Factors in Plants. Aspects of Applied Biology, 1973, 19, pp 21-25.

[19] P. Schuler, Natural antioxidants exploited commercially. Food Antioxidants, Elsevier Applied Food Science Series, 1990, pp 99-170.

[20] R. A. Day and A. L. Underwood, Qualitative aAnalysis. $5^{\text {th }}$ Ed. New Delhi, India: Prentice Hall Publications, 1986, pp 701.

[21] E. I. Wheeler and R. E. Ferrel, Methods For phytic acid determination in wheat and wheat fractions. Journal of Cereal of Chemistry. 1971, 48, pp 312-320.

[22] I. E. F. Benzie and J. J. Strain, The ferric reducing ability of plasma (FRAP) as ameasure of antioxidant power: the FRAP assay. Analytical Biochemistry, 1996, 239, pp 7076.

[23] P. Valentao, E. Fernandes, F. Carvalho, P. B. Andrade, R. M. Seabra, and M. L. Bastos, Antioxidant properties of cardoon (Cynara cardunculusL.) infusion against superoxide radical, hydroxyl radical, and hypochlorous acid. Journal Agricultural Food Chemical, 2002, 50, pp 4989-4993.

[24] R. P. Adams, Identification of Essential Oil Components by Gas chromatography/Quadrupole Mass spectroscopy. Allured Publishing Corporation, Carol Stream, Illinois, USA, 2007.

[25] A. T. Orishadipe, J. I. Okogun, and E. Mishelia, Gas chromatography - mass spectrometry analysis of the hexane extract of Calliandra portoricensis and its antimicrobial activity. Afri J Pure and Appl Chem, 2010, 4, pp 131-134.

[26] S. Stein, D. Mirokhin, D. Tchekhovskoi, G. Mallard, The NIST Mass Spectral Search Program for the NIST/EPA/NIH Mass Spectra Library. Standard Reference Data Program of the National Institute of Standards and Technology. Gaithersburg, MD, US; 2002.

[27] U. A. Essiett and I. E. Bassey, Comparative Phytochemical Screening and Nutritional Potentials of the Flowers (petals) of Sennaalata(L) roxb, Sennahirsuta(L) Irwin and barneby, and Sennaobtusifolia(L.)Irwin and barneby (Fabaceae). Journal of Applied Pharmaceutical Science, 2013, 3, pp 097-101.

[28] L. A. Maynard,. Animal Nutrition. McGraw Hill book company Ltd. New York, 1997, pp. 47.
[29] S. G. Sparg, M. E. Light, and J. V. Stadan, Biological Activities and Distribution of Plant Saponins. Journal of Ethnopharmacology, 2004, 94, pp 219-243.

[30] U. Veerachari, and A. K. Bopaiah, Preliminary phytochemicalevaluation of the leaf extract of five Cassia species. Journal Chemical Pharmacology Resource, 2011, 3 pp 574-583.

[31] U. A. Essiett, D. N. Bala, and J. A. Agbakahi, Pharmacognosticstudies of the leaves and stem of DiodiascandensSW in Nigeria. Archives of Applied Science Research, 2010, 2, pp 124-198.

[32] M. T. Trease and S. E. Evans, The Phytochemical Analysis and Anti-bacterial Screening of Extract of Some Common Vegetables.Chemical Science, Nigeria, 1989, 26, pp57-58.

[33] E. Bell, Vitamin D3 promotes immune function on the skin.http//www.signalinggateway.org/upd ate/updates/ 2007.

[34] O. M. Iniaghe, S. O. Malomo and J. D. Adebayo, Proximate composition and Phytochemical constituents of leaves of some Acalyphaspecies. Journal of Nutrition, 2009, 8, pp256- 258.

[35] A. Taiwo, C. Abidemi, J. Oyedepo, B. Adebayo, I. Oluwadare, and D. Agboto, Nutrient content and antinutritional factor in Shea butter (Butryospermum parkii) leaves, African Journal of Biotechnology, 2009, 8, pp 5888-5890.

[36] J. A. Duke, Handbook of Medicinal Herbs. CRC press Inc. Boca Raton, Fla, 1985, pp72-80.

[37] A. O. Awoyinka, I. O. Balogun, and A. A. Ogunnowo, Phytochemical screening and in-vitro bioactivity of Cnidoscolusaconitiifolus (Euphorbiaceae), Journal of Medicinal plants Research, 2007, 1, pp 63-65.

[38] J. T. McDevitt, D. M. Schneider, S. K. Katiyar, and F. S. Edlind, .Berberina: a candidate for the treatment of diarrhea in AIDS patients abstract 175, In program and Abstracts of the 36th Interscienceonference on Antimicrobial Agents and Chemotherapy, American Society for Microbiology, Washington, D. C. 1996.

[39] A. Scalbert,.Antimicrobial properties of tannis, Phytochemistry, 1991, 30, pp 3875-3882.

[40] P. Siddhauraju, and K. Becker, Nutritional and antinutritional composition, in vitro amino acid availability, starch digestibility and predicted glycemic index of differently processed mucuna beans (Mucuna pruriens var. utilis): An underutilized legume. Food Chemical, 2005, 91, pp 275-286.

[41] R. Riguera, Isolating bioactive compounds from marine organisms. Journal Marine Biotechnology, 1997), 5, pp187-193.

[42] I. Abdulwaliyu, S. O. Arekemase, S. Bala, A. S. Ibraheem, A. M. Dakare, R. Sangodare, and M. Gero, Nutritional Properties of Senna alata Linn Leaf and Flower. International Journal of Modern Biology and Medicine, 2013, 4, pp1-11.

[43] R. Hegnauer, Chemical Plant Taxonomy. Academic Press Inc., New York, 1963, p. 389.

[44] W. Richard, E. Katie and T. Ferrell, Squirrels: the animal answer guide. Baltimore: Johns Hopkins University Press. seeds. Pakistan Journal of Nutritional, 2006, 6, pp40-43.

[45] E. S. Mitchikpe, Determination of of chemical composition of Prosopis africana, Journal of Food Composition Analysis, 2008, 21, pp17-23. 
[46] F. L. Ola and G. Oboh, Anti-nutritional Factors, in Nutritional Quality of Plant Foods. The Journal Technoscience, 2000, 4, pp1-3.

[47] S. R. J. Maxwell, Prospects for the use of antioxdant therapies. Drugs, 1995, 49, pp345 - 361

[48] B. Halliwell, J. M. C. Gutteridge, Free radicals in Biology and Medicine $2^{\text {nd }}$ Edition. Clarendon Press, Oxford. 1989, pp416 494.

[49] D. Karou, M. H. Dicko, J. Simpore, S. A. Traore, Antioxidant and antibacterial activities of polyphenols from ethnomedicinal plants of Burkina Faso. Afr J Biotechnol, 2005, 4, 823-828.

[50] A. B. Aliyu, M. A. Ibrahim, H. Ibrahim, A. M. Musa, A. Y. Lawal, J. A. Oshanimi, M. Usman, I. E. Abdulkadir, A. O. Oyewale, J. O. Amupitan, Free radical scavenging and total antioxidant capacity of methanol extract of Ethulia conyzoides growing in Nigeria. Romanian Biotechnological Letters, 2012, 17, pp7458-7465.
[51] O. Olajide, D. Idowu, S. Okolo, A. Orishadipe, T. Sunday, Phytochemical and antioxidant properties of some Nigerian medicinal plants. Am J Sci Ind Res, 2013, 4, 328-32.

[52] J. M. Oke, M. O. Hamburger, Screening of some Nigerian Medicinal Plants for antioxidant activity using 2,2, diphenylpicyl-hydrazyl radical. Afr. J. Biomedical Res, 2002, 5, 77-79.

[53] P. Buran, P. Supak, Antioxidant Capacities of Pueraria mirifica,Steviare baudiana Bertoni, Curcuma longa Linn., Andrographis paniculata (Burm.f.) Nees. and Cassia alata Linn.for the Development of Dietary Supplement.Kasetsart Journalof Natural Science, 2007, 41, 548 - 554.

[54] M. A. Adebayo, O. A. Lawal, A. A. Sikiru, I. A. Ogunwande, O. N. Avoseh, Chemical Constituentsand Antimicrobial Activity of Essential Oil of Senna podocarpa (Guill. Et Perr.) Lock. American Journal of Plant Sciences, 2014, 5, 24482453.

[55] M. Law, Dietary fat and adult diseases and the implications for childhood nutrition: An Epidemiologic approach. American. Journal Clinic Nutrition, 2000, 72, pp1291s-1296s. 